\title{
Lords of the Harvest: Third-party Influence and Regulatory Approval of Genetically Modified Organisms
}

\section{Citation}

Hiatt, Shon R., and Sangchan Park. "Lords of the Harvest: Third-party Influence and Regulatory Approval of Genetically Modified Organisms." Academy of Management Journal 56, no. 4 (August 2013): 923-944.

\section{Published Version}

http://dx.doi.org/10.5465/amj.2011.0128

\section{Permanent link}

http://nrs.harvard.edu/urn-3:HUL.InstRepos:12534913

\section{Terms of Use}

This article was downloaded from Harvard University's DASH repository, and is made available under the terms and conditions applicable to Open Access Policy Articles, as set forth at http:// nrs.harvard.edu/urn-3:HUL.InstRepos:dash.current.terms-of-use\#OAP

\section{Share Your Story}

The Harvard community has made this article openly available.

Please share how this access benefits you. Submit a story.

\section{Accessibility}




\title{
Lords of the Harvest: Third-party Influence and Regulatory Approval of Genetically Modified Organisms
}

\author{
Shon R. Hiatt \\ Harvard University \\ Boston, MA \\ shiatt@hbs.edu \\ 617-495-6656 \\ Sangchan Park \\ Ewha Womans University \\ Seoul, Korea \\ scpark@ewha.ac.kr \\ and \\ National University of Singapore \\ Singapore
}

\section{ACKNOWLEDGMENTS}

The authors thank Associate Editor Tim Pollock and the anonymous reviewers for their guidance and Julie Battilana, Sea-Jin Chang, Chi-Nien Chung, Chad Carlos, Michael Gore, Ranjay Gulati, YoungChoon Kim, Brandon Lee, David Lehman, Chris Marquis, Lakshmi Ramarajan, Wesley Sine, Pamela Tolbert, Michael Tushman, and David Whetten for helpful comments on earlier drafts of the paper. We also thank participants from the Alliance for Research on Corporate Sustainability and the Strategy and the Business Environment conferences as well as seminar participants at Dartmouth College, Massachusetts Institute of Technology, the University of Southern California, Ewha Womans University, Korea University, and Yonsei University for their helpful criticism. Portions of this research were supported by the Harvard Business School Division of Research. The authors contributed equally. 


\title{
LORDS OF THE HARVEST: THIRD-PARTY INFLUENCE AND REGULATORY APPROVAL OF GENETICALLY MODIFIED ORGANISMS
}

\begin{abstract}
Little is known about the factors that influence regulatory-agency decision making. We posit that regulatory agencies are influenced by the firms they regulate, but not exclusively via dyadic exchanges as is traditionally argued in the regulatory capture and business-government literatures. Instead, regulatory decisions are indirectly shaped via third-party actors who shield agencies from legitimacy threats. Focusing empirically on the U.S. Department of Agriculture's approval of genetically modified organisms (GMOs), we find that product assessments by powerful stakeholders and peer agencies influence product approval and that their effects vary under different threats. We also discuss the implications of these findings for businessgovernment relations, nonmarket strategy, and organization theory.
\end{abstract}

Keywords: Organization theory, business-government relations, nonmarket strategy, private and public politics 


\section{INTRODUCTION}

Government is relevant to virtually every business sector, but regulated industries like biotechnology, telecommunications, electricity, and pharmaceuticals are particularly subject to state intervention. In such industries, government can dramatically influence firm performance and survival via regulatory approvals or disapprovals of product and service offerings, product standards and production requirements, and market entry and exit rules (Sine, Haveman, \& Tolbert, 2005; Garcia-Canal \& Guillen, 2008). Given the significance of public policy, much of the research on business-government relations has focused on regulatory change, its impact on industries and organizations, and firm efforts to influence policymakers, a concept often called regulatory capture (Hillman \& Keim, 1995; Dobbin \& Dowd, 1997; Bonardi, Hillman, \& Keim, 2005).

While insightful, this work has two notable limitations. First, studies have almost exclusively focused on policy making by legislators and have neglected policy implementation by regulatory agencies, a serious omission, in that regulatory agencies have more contact with businesses than legislators do via day-to-day interpretation and execution of laws (Sabatier \& Mazmanian, 1980). Second, prior work has generally examined the macro-level influences of public policy on entire industries, whereas there has been sparse inquiry into organizational-level regulatory outcomes (Dal Bo, 2006; Trumbull, 2012). Taken together, we still have little understanding of the behavior of government agencies in business-government relations and, in particular, of such agencies' impact on firm performance (Holburn \& Vanden Bergh, 2002).

This paper seeks to remedy this situation by putting regulatory agencies on center stage. We view regulatory agencies as social actors striving to protect their legitimacy in order to secure their interests, autonomy, and access to resources (Skocpol, 1985; Suchman, 1995; King, 
Felin, \& Whetten, 2010). Legitimacy is a precious asset for almost all organizations, but it is particularly critical for regulatory agencies given their high dependence on external resources and support from their various audiences (Carpenter, 2001). Because the legitimacy of regulatory activities can rest on those audiences' assessments (Deephouse \& Suchman, 2008), we introduce a framework that differentiates between two dimensions of legitimacy assessments, pragmatic and procedural. Pragmatic legitimacy rests on the evaluation of whether the actions of agencies maximize audiences' utility, whereas procedural legitimacy rests on broader normative evaluation of whether agencies follow socially accepted procedures and practices likely to lead to socially valued ends (Suchman, 1995). Our central argument is that regulatory agencies face threats to their legitimacy, and that they manage these threats by relying upon the assessments of prominent third-party actors who can serve as shields that protect their legitimacy. We show how these actors affect regulatory decision making, and how their influence varies with several risk factors associated with regulated firms and their products.

The context of our study is regulatory approval of genetically modified organisms (GMOs) by the U.S. Department of Agriculture (USDA) between 1992 and 2007. Like many other government agencies, the USDA strives to strengthen its autonomy and power by preserving and promoting pragmatic and procedural legitimacy. We suggest that the USDA contends with two corresponding risks that threaten its legitimacy. In protecting its pragmatic legitimacy, the USDA must manage external risks, or risk factors exogenous to the approval process, such as audiences whose assessments are based on diverse, often conflicting, utility calculations with respect to the outcomes of agency decision-making. In protecting its procedural legitimacy, the USDA must manage internal risks, or risk factors endogenous to the review process, such as agricultural safety and environmental protection via formal procedures and 
techniques that are normatively approved, but remain incomplete in terms of the capacity to acquire and process scientifically decisive evidence of GMO safety. Because these risks, if unresolved, can threaten the USDA's legitimacy, the agency strives to manage them by relying on prominent third-party actors like powerful stakeholders and peer agencies.

Our paper makes several important contributions. First, it contributes to the businessgovernment relations and regulatory capture literatures by examining the underexplored role of regulatory agencies in policy implementation, thereby moving beyond prior work that has focused on political influence in market-like dyadic interactions between policy suppliers and demanders (Hillman \& Hitt, 1999; Bonardi, Hillman, \& Keim, 2005). Second, this paper contributes to the stakeholder management literature by examining under what conditions the influences of stakeholders on regulatory decisions matter more (Eisenhardt \& Zbaracki, 1992; Mitchell, Agle, \& Wood 1997; Vasi \& King, 2012). The paper also adds to institutional theory by bringing agency back into studies involving the state (Skocpol, 1985; King et al., 2010). Finally, the study contributes to the strategic management literature by exploring how regulatory agencies' approach to managing legitimacy risk creates conditions in which firms can indirectly influence regulatory decision making (Hillman \& Keim, 1995). It thus offers extensive implications for regulatory agencies, policy makers, and firms in regulated environments.

The next section will describe the context of this study: the process of regulatory approval of GMOs in the agribusiness market. The paper will then offer a framework that highlights the distinctions between pragmatic and procedural legitimacy and between the corresponding legitimacy risks. We will explain how regulatory agencies rely on assessments by third-party actors, namely, powerful stakeholders and peer agencies that can reduce the risk of legitimacy damage. Finally, we will examine how the influence of agency stakeholders and peer 
agencies are contingent on various internal and external risks that threaten legitimacy.

\section{RESEARCH SETTING: APPROVAL OF GENETICALLY MODIFIED ORGANISMS}

This paper examines the approval of genetically modified plants, or plant organisms, the genetic material of which has been altered using genetic-engineering techniques to enhance such desired traits as herbicide resistance, pesticide properties, and nutritional content. The first successful genetically modified product to come to market, in 1992, was Calgene's Flavr Savr tomato, which did not soften or spoil and thus could sit on grocery-store shelves weeks longer than normal tomatoes. Other agro-chemical and seed companies followed suit with their own commercial GMOs. Monsanto introduced the first herbicide-resistant plant, Roundup Ready soybeans, in 1993. Over the next 12 years, agriculture biotechnology companies commercialized favorable traits in 19 plant varieties. By the end of 2006, 61 percent of the corn and 89 percent of the soybeans grown in the United States were GMO varieties, and nearly 70 percent of all supermarket products had some GMO content (IFIC, 2007).

Genetically modified plants are regulated under the Coordinated Framework for the Regulation of Biotechnology, which governs federal policy on regulating the development and market introduction of GMOs and the product-review and approval procedures of involved agencies. Responsibility for regulatory oversight of GMOs is primarily entrusted to the USDA, which is charged with ensuring the environmental safety of GMO crops and approving market

introductions. The framework also specifies that the Environmental Protection Agency (EPA) is to supervise approved substances with pesticide properties and the Food and Drug Administration (FDA) to act as an optional consultant to affirm the accuracy of nutritional labeling on food products that contain GMOs; companies seeking USDA approval of GMOs are not required to consult the FDA or, if they do so, to follow its recommendations. 
The USDA was legally established to "acquire and diffuse . . . useful information on subjects connected with agriculture" and to "procure, propagate, and distribute among the people new and valuable seeds and plants" (USDA, 2012a). Prevailing laws that govern regulatory policy for the USDA, such as the Coordinated Framework for the Regulation of Biotechnology and the Plant Protection Act, specify that these general duties should be performed via formal review procedures that rest on "sound science" and efficient review processes. The USDA's mission statement appears to reflect this emphasis on science and efficiency: "We provide leadership on food, agriculture, natural resources, and related issues based on sound public policy, the best available science, and efficient management" (USDA, 2012b). The USDA has created formal approval processes by means of which to examine environmental hazards of GMOs via scientifically rigorous methodologies, and thus to enhance food safety and the wellbeing of the people of the U.S. population (USDA, 1996). When a biotechnology firm prepares for commercialization of a GMO product, it petitions the USDA for product approval. The petition for approval describes the genetic transformation and its potential environmental consequences by providing a variety of information, such as the breeding history of the transgenic plant population; comparisons of growth habits, life spans, vegetative vigor, and pollen parameters; compatibility with wild species; and the potential consequences of gene flow to other species. The USDA's Animal and Plant Health Inspection Service conducts an in-depth scientific assessment to evaluate the validity of the information provided by the firm, and to determine whether the organism can safely be released into the environment.

These formal procedures are designed to collect scientifically decisive evidence on safety issues, but even the most rigorous scientific techniques cannot uncover all the potential dangers of a given product with complete certainty in advance (Conner, Glare, \& Nap, 2003). For 
example, horizontal transfer of GMO genes with herbicide properties to wild plant varieties could foster the growth of indestructible weeds that could reduce agricultural yields and even wreak havoc on an entire ecological system. Hence, USDA scientists cannot hope to specify the potential impact of GMO genes on every kind of organism (plant, animal, and microbial), or even on those in close proximity to genetically modified plants (Hails \& Morley, 2005). Once the USDA has sorted through the available information and made a preliminary decision, it prepares an environmental document for public comment. After considering the comments, it publishes a response outlining whether it deems the product safe for market. If a product is approved and later deemed unsafe, the USDA retains the authority to take it off the market.

\section{THEORY AND HYPOTHESES}

\section{Legitimacy of Regulatory Agencies}

The portrait of regulatory agencies routinely presented by sociologists and institutional economists is that of public agencies that do not always regulate markets for the benefit of society at large, but often pursue their own interests in capturing greater autonomy and resources (Skocpol, 1985; North, 1990). In support of this thesis, prior work has shown that regulatory agencies attempt to maximize their own budgets, expand their workforces, and enhance the career prospects or political reputations of their directors (Niskanen, 1971; Weatherby, 1971; Mueller, 2003). Although there are many ways in which regulatory agencies can assert themselves, they often seek to strengthen their autonomy and power by preserving and promoting their intangible assets. Legitimacy, in particular, can shape the perceptions of legislators, Cabinet members, and other key resource holders, and thus affect an agency's autonomy, discretion, and resource acquisition (Carpenter, 2001; Deephouse \& Suchman, 2008; King et al., 2010). 
No federal agency understands the relationship between legitimacy and the pursuit of autonomy, resources, and responsibility better than the USDA. Since its founding in 1889, the Department has enjoyed an "unusual degree of administrative unity and flexibility" (Skocpol \& Finegold, 1982: 272). For example, few subdivisions within the Department were legislatively created by Congress, and all employees except the top officials are subject to appointment and removal by the head of the Department, the Secretary of Agriculture; consequently, successive Secretaries of Agriculture could shape their agency without pre-approval by Congress. However, the agency has not gone unchallenged. During the post New-Deal years, for instance, a conservative Congress as well as hostile elite farmers wanted greater influence over the way the USDA allocated agriculture subsidies and demanded that it demote the Bureau of Agricultural Economics from its powerful budgeting role within the agency. Nevertheless, the USDA managed to refuse their orders (Hooks, 1990). The rewards of legitimacy are well illustrated by the USDA's takeover of 193 million acres of federal forest lands in the early twentieth century from the Department of the Interior — one of the oldest and largest Cabinet departments — the legitimacy of which was damaged by its mishandling of Civil War veterans' pensions and squandering of Reclamation Act monies. Hence, legitimacy is important not only for protecting existing autonomy, responsibility, and resources, but also for gaining more.

We suggest that regulatory agencies seek to protect two distinct dimensions of legitimacy: pragmatic and procedural. Suchman's (1995) conceptual typology of legitimacy spells out distinctions among these and other types of legitimacy. One type, pragmatic legitimacy, rests on evaluations of whether an organization's actions maximize audiences' utility. Audiences may support an organization because they obtain immediate material benefits or because they believe it is committed and responsive to their larger interests. In either case, audiences' positive 
assessments of an agency's decisions can serve as a solid basis for pragmatic legitimacy, and thus protect the agency's autonomy, resources, and responsibility (Delmas \& Toffel, 2004).

The other type, procedural legitimacy, is a component of moral legitimacy that reflects "a positive normative evaluation of the organization and its activities" (Suchman, 1995: 579). The assessment of procedural legitimacy rests on audience judgments of whether regulatory decisionmaking processes follow socially accepted methodologies. Audiences may support an agency if it exhibits normative compliance and follows scientific procedures and techniques that are appropriate to achieving valued ends. Adhering to such procedures demonstrates good-faith efforts to achieve valued ends, particularly in the absence of clear outcome measures (Suchman, 1995; Scott, 1992), as well as represents conformity to culturally established beliefs and rules that validate science as a central principle on which modern societies are founded (Thornton \& Ocasio, 2008).

Protecting these types of legitimacy, however, is challenging. Regulatory agencies face external risks to their pragmatic legitimacy when they cannot address the needs of all their stakeholders. The USDA, for example, faces a wide variety of stakeholders, or individuals and businesses affected by the agency's services, operations, and functions (Clarkson, 1995; Mitchell, Agle, \& Wood, 1997), including individual farmers, consumer and food-safety organizations, colleges and universities, professional science societies, and environmental activist groups. Given the diverging interests of these stakeholders, the pragmatic assessments of a regulatory decision cannot always rest on a unanimous evaluation. This circumstance makes it difficult for the agency to balance the various interests and remain responsive to the utility of all audiences. In this situation, some audiences are likely to be dissatisfied and to provide negative evaluations that can threaten pragmatic legitimacy. 
Regulatory agencies also face internal risks to their procedural legitimacy when the probability of making a poor scientific decision is high. As noted earlier, GMOs build on a complex set of biotechnological techniques that can potentially undermine environmental safety and health issues. Thus scientific methodologies for analyzing the safety issues surrounding GMOs are central to the USDA's decision processes. However, it is almost impossible to obtain perfect information with which to analyze all potential dangers and future environmental impacts. This challenge increases the risk of approving a dangerous product, which would negatively affect audience judgments surrounding the agency's competency and ability to methodologically assess product risks. For instance, if the USDA were to approve a poor product, it could be the object of embarrassing congressional hearings that could further erode its legitimacy, autonomy, and resources. ${ }^{1}$

\section{Legitimacy risk management and third-party actor influence}

How do regulatory agencies like the USDA manage legitimacy risks? We propose that regulatory agencies do so by relying on third-party actors that can serve as shields that insulate agencies from internal and external threats. This notion of organizational shields has been explored in organization theory research. For example, in their study of the founding, transformation, and dissolution of Finnish newspapers, Miner and colleagues (1990) found that powerful political parties served as shields for newspaper companies by facilitating access to resources and legitimacy when these firms were at risk of failure during periods of organizational transformation. Extending this research, Fischer and Pollock (2004) explored failure risks of new ventures and found that particular actors, founder CEOs, served as shields that protected the ventures' legitimacy from outside threats associated with initial public offering. Consistent with

\footnotetext{
${ }^{1}$ In 2007 and again in 2010, the USDA was forced by court order to pull two approved GMOs off the market for not conducting thorough environmental assessments. Congressional hearings followed, pointing out the agency's procedural inadequacies and threatening greater congressional oversight.
} 
this literature, we highlight the role that third-party actors, powerful stakeholders and peer agencies, can play in shielding a regulatory agency against threats to its pragmatic and procedural legitimacy. We explore how each group of actors employs a different mechanism that protects against legitimacy damage, thereby affecting regulatory decisions.

External risks and the influence of powerful stakeholders. When a government agency faces external risks to its pragmatic legitimacy in its regulatory decision making, it is likely to manage these risks by focusing on the assessments of powerful stakeholders that can protect the agency's autonomy, legitimacy, and resources. Following the convention of defining power in terms of degree of dependence (Pfeffer \& Salancik, 1978), we suggest that the most powerful stakeholders are those that have the greatest sway in affecting the lawmakers who oversee and determine an agency's resources, autonomy, and responsibility. As such, we consider farm associations that represent organized farmers to be the most powerful stakeholders of the USDA.

Historically, the USDA has viewed farmers as one of its key audiences. During the Great Depression, for example, farm associations established close relationships with the House and Senate agriculture committees; at the same time, according to one scholar, "officers of the Department of Agriculture recognized farm organizations as consultative organs in themselves" and relied on them when crafting and interpreting New Deal farm policy (McConnell, 1953: 75). During the Second World War, the influence of farm associations was still apparent in the implementation of agriculture policy, as one historian has noted: "Although the national interest was compromised, the narrow interests of elite farmers were well served-they made excessive profits, producing unneeded and expensive goods" (Hooks, 1990: 36). Fifty years later, despite lobbying by a multiplicity of competing groups, farmers and farm associations still remained powerful USDA stakeholders, as one farm-association staffer observed: "I think that the USDA 
feels that we are important constituents. If we have something to say, they listen. If we are against something, the USDA tries not to go against what we say. If we are in favor of a policy, they try to agree with us."

Farm associations often hold meetings with biotechnology firms in which they learn about GMO products in the pipeline and discuss farmers' needs. If a farm association is convinced that a new product will improve its members' businesses, it may inform its members and advocate for the product's approval. "We have an advocacy group that meets with different seed companies, and we have discussions offline, and they share information with us," explained an employee of a statewide association of soybean farmers. "If the products seem good, we then advocate the next generation of GMO seeds to be approved." A representative of a different state soybean association elaborated: "Seed companies will invite the corn, soybean, and other association members to talk about their products in the pipeline, and invite us to support their products. If their products are not supported by us, it could really hurt them and their chances for approval."

Because the USDA cannot satisfy all of its stakeholders with its regulatory decisions, it is likely to rely on its most powerful stakeholders, which can provide influential assessments of the agency. Product-approval requests from farm associations inform the agency that if it approves a particular product, it will receive positive assessments from farmers and reduce the risk that disaffected stakeholders can damage its legitimacy. USDA decision reports highlight approval requests received from farm associations and the Department's alignment with their endorsements. For example, the USDA reported that farm associations' requests for approval of Monsanto's corn variety \#863 “stressed . . . the advantages to growers in increased yields and crop quality" (APHIS, 2005: 1). Thus, we argue that assessments by powerful stakeholders will 
affect the decision making of regulatory agencies.

Hypothesis 1: Positive assessments from an agency's powerful stakeholders (e.g., farm associations) will increase the likelihood of product approval.

Internal risks and the influence of peer agencies. As noted, it is near-impossible for the USDA to obtain, via review procedures, all the information needed to completely analyze the possible dangers of a new product in all environments, which imposes threats to procedural legitimacy. We suggest that regulatory agencies manage these risks by relying on external expertise that can supplement the review process (Olson, 1997). Peer organizations with similar practices and competencies often serve this function. During product review, an agency may look to peer agencies that it believes to possess pertinent evaluative abilities that can effectively identify sources of environmental hazards.

The FDA is the USDA's most prominent peer agency. Arguably one of the most powerful regulatory agencies in the world, the FDA is believed to have sophisticated scientific capabilities with which to evaluate the safety of food and drugs (Olson, 1997; Carpenter, 2002, 2004). Given the perceived authority of the FDA's scientific evaluations of food safety, USDA officials tend to assign high value to the FDA when reviewing the safety of GMOs. The FDA does not grant regulatory approval to GMOs, but it can act as an optional consultant to biotechnology companies on nutritional and other regulatory issues related to bioengineered products. During the consultation, the GMO developer submits a summary of its scientific and regulatory assessment of the food to the FDA's Center for Food Safety and Applied Nutrition, a biotechnology evaluation team of which reviews the data. The company ultimately receives a consultation memorandum or certificate describing any nutritional labeling issues that have been raised and resolved. A typical memorandum provides information not only on calories, vitamins, and minerals, but also on potential allergens, an important source of safety concerns. A copy of 
the memorandum is forwarded to the USDA.

An FDA consultation is relevant to the USDA's review procedures. It confirms the appropriateness of the nutritional labeling, enhancing the general credibility of the information the regulated firm provides in its petitions. It also confers more specific confidence on safety issues like allergens. The USDA can build on the FDA-certified information in its safety analysis, and can extend it by doing further evaluative testing to identify other safety issues. Thus, by providing credible information and procedures to help the USDA better evaluate products' risks, an FDA consultation can serve as a shield against threats to procedural legitimacy. USDA decision reports often include references to FDA memoranda and indicate that review procedures incorporate FDA-generated information. Hence, we argue that assessments by peer agencies will affect the decision making of regulatory agencies.

Hypothesis 2: Positive assessments from peer agencies (e.g., the FDA) will increase the likelihood of product approval.

\section{The Contingencies of Third-Party Influences on Regulatory Decision Making}

The hypothesized mechanism of third-party influence on regulatory decisions highlights how government agencies rely on other prominent actors to manage legitimacy risks. This section will further strengthen our argument by examining the contingent value of third-party influence under varying degrees of legitimacy threats. If our proposed mechanism actually operates, we should expect the main effects to become stronger when agencies face higher risks of legitimacy damage. Moreover, because our causal arguments rest on two dimensions of legitimacy, we expect that third-party influence will vary only with the degree of corresponding sources of threats associated with each of the two legitimacy types. We focus on two external threats (congressional electoral competitiveness and activist protests) and two internal threats (involvement of a foreign company and technological novelty). Figure 1illustrates the theoretical 
model embodied in our arguments.

---Insert Figure 1 about here---

Congressional electoral competitiveness and collective protest. Because pragmatic

legitimacy depends on evaluative judgments of external audiences, an agency's reliance on powerful stakeholders will likely vary according to the level of external threats associated with those audiences. First, the USDA will face greater risk when it has to consider a larger number of influential audiences and the potential that Congress will exert greater power over the agency. Second, the USDA will also face greater risk when certain audiences create public controversies over its GMO approval decisions. Given these greater threats to pragmatic legitimacy, the USDA will become more motivated to rely on powerful stakeholders to manage the risk of legitimacy damage. We focus on congressional electoral competitiveness and collective protest as indicators of two such conditions.

Congressional electoral competitiveness is a measure of the closeness of political races between candidates. Research in political science and sociology posits that greater electoral competitiveness over congressional seats tends to be associated with higher legislative responsiveness to the public's interests (Hill, Leighley, \& Hinton-Andersson, 1995); politicians become more sensitive to a greater number of voters who raise accountability issues including both major and minor groups that would not receive political attention under conditions of low electoral competitiveness. For example, scholars have shown how electoral competitiveness increased legislators' responsiveness to relatively weak collective activists in passing politically liberal bills that favored their interests (Soule \& Olzak, 2004; Soule \& King, 2006). Hence, as politicians become more sensitive to the demands of various major and minor groups, the USDA will be forced to pay attention to a broader range of stakeholders with greater political influence, 
thereby increasing the chance that some stakeholders will not be satisfied.

Additionally, high electoral competitiveness can stimulate lawmakers to engage in more active congressional oversight and meddling in the USDA's affairs by creating a conviction that “something must be done” (Skocpol \& Finegold, 1982: 277; Besley \& Burgess, 2002). Under this conviction, the USDA faces a greater risk of dissatisfying some lawmakers who oversee and the potential that Congress will increase its power over the agency. Consequently, the USDA will face a higher risk of losing autonomy, resources, and responsibility, and will more likely rely on its powerful stakeholders, farm associations, to protect the agency. Hence, the influence of powerful stakeholders on agency decision making will be greater under high election competition.

Hypothesis 3: Powerful stakeholders (e.g., farm associations) will have greater influence on a regulatory agency's (e.g., the USDA's) decision making when the risk of losing pragmatic legitimacy is high due to the political environment (e.g., competitive congressional races).

Protests are a form of public action that calls for the involvement of previously uninterested audiences in fostering change among organizations (King \& Soule, 2007). In the agro-biotechnology sector, environmental activists often protested against GMOs under review, arguing that GMOs were environmentally destructive (Charles, 2001). Protests increase both audience involvement and the protester groups' influence by denigrating particular practices and convincing others of the need for change (King \& Pearce, 2010). For example, by framing products under review as environmentally harmful and toxic and politicizing regulatory decisions, anti-GMO protesters can vilify both the product and the government agency, making the latter appear less independent, professional, and competent (Peretti, 2004). For the USDA, protests represent a significant threat to its legitimacy. The agency will then more likely rely on assessments of its most influential stakeholder, farm associations. Therefore, we argue that the 
influence of farm associations on agency decision making will be stronger under collective protests.

Hypothesis 4: Powerful stakeholders (e.g., farm associations) will have greater influence on a regulatory agency's (e.g., the USDA's) decision making when the risk of losing pragmatic legitimacy is high due to public controversies (e.g., collective protests).

Foreign companies and technology novelty. Unlike threats to pragmatic legitimacy, which are largely external in nature, those to procedural legitimacy are internal, as they stem from the qualities of producers or products that pose challenges to an agency's endeavor to rely on formal review processes. Foreign biotechnology firms that develop GMOs in their home countries and then petition the USDA for approval in the United States may face unfavorable decisions, particularly if they develop and test their products under different regulatory supervision and decision procedures than those of the United States. Confidence in the ability of foreign regulatory agencies to evaluate food safety has been eroded by highly publicized food scares in Europe (Jacob \& Hellstrom, 2000; Knowles, Moody, \& McEarchen, 2007). In the early 1980s, tens of thousands of people became sick and over 800 people died in Spain from cooking oil contaminated with aniline, a toxic industrial chemical. Approximately a decade later, British regulatory agencies failed to recognize and contain bovine spongiform encephalopathy, "madcow disease," which infected thousands of cattle and killed nearly 200 people (McNeil, 2006). A few years later, Belgian regulatory agencies were discovered trying to cover up the leakage of a highly carcinogenic chemical, polychlorinated dibenzodioxin, into animal feed; over seven million chickens and 60,000 pigs had to be euthanized. More recently, a British agency was slow to recognize and report highly infectious foot-and-mouth disease, which then spread throughout Britain, threatened animals in continental Europe, and led to the slaughter of over 7 million cattle (Rivers, 2007). 
With such failures in mind, the USDA may well believe that GMOs developed and tested under the auspices of foreign regulatory agencies will be less safe than those developed and tested under its own scrutiny, and may therefore subject those products to more critical investigations. On the other hand, memoranda from a prominent peer agency, such as the FDA, may become more valuable if they provide positive information on such products. Thus, we predict that a consultation from the FDA will have a stronger positive effect on the USDA's decision making when the GMO is made by a non-U.S. company.

Hypothesis 5: Peer agencies (e.g., the FDA) will have greater influence on a regulatory agency's (e.g., the USDA's) decision making when the risk of losing procedural legitimacy is high due to little regulatory supervision (e.g., GMOs developed by non-U.S. companies).

Genetically modified organisms characterized by novel components and technologies, such as new transgenic procedures, are at greater risk in regulatory review processes. First, new technologies are inherently characterized by lack of information about their quality and relevance. Second, evaluation procedures have rarely been established for such new technologies. Regulatory agencies may thus have to develop new and untested evaluation procedures and techniques, which may lead to unfavorable decisions. Again, positive memoranda from a peer agency can become more influential if they serve as reliable supplementary information. Thus, we predict that a consultation from the FDA will have a stronger positive effect on the USDA's decision making when the manufacturer used novel technologies to develop the GMO product under review.

Hypothesis 6: Peer agencies (e.g., the FDA) will have greater influence on a regulatory agency's (e.g., the USDA's) decision making when the risk of losing procedural legitimacy is high due to risky products (e.g., GMOs that embody novel technologies).

\section{METHODS}

\section{Data and Measures}


Our sample consists of all petitions for approval of GMOs between June 1992, when the first such petition was submitted, and December 31, 2007, the last date for which suitable data are available. During this period, 113 petitions for genetically modified plant products were submitted by 29 companies; 73 (65 percent) gained approval, 28 (24 percent) did not, and 12 (11 percent) were still awaiting a decision at the end of the study period.

Dependent variable. Our dependent variable is GMO approval events by the USDA. We used an event-history analysis rather than a logistic analysis because the former maximizes the use of available information (such as time to approval) and is the standard approach used in research on a similar phenomenon, pharmaceutical approval (Carpenter, 2002). Data on petitions for approval came from the USDA's Animal and Plant Health Inspection Service. This dataset contains information on the petitioning firm, the species or crop in question, the date the request was received by the USDA, the start and end dates of the Federal Register comment period, the status of the request, whether the application contains confidential business information, and the phenotype category and genotype (donor and gene designation) of the material in question.

Predictor variables. Our predictor variables are approval requests from powerful stakeholders (e.g., farm associations) and positive memoranda from peer agencies (e.g., the FDA) prior to a USDA decision as well as congressional electoral competitiveness, GMO protests, participation of a foreign company, and novel technology. About 34 percent of the petitions received farm association endorsements and about 35 percent received a completed FDA consultation memorandum prior to the USDA decision. ${ }^{2}$ To capture influence from farm

\footnotetext{
${ }^{2}$ We conducted a linear and logistic analysis to determine whether any characteristics of firms or GMOs would make some more likely than others to garner farm association support and and/or to request an FDA consultation. We found that firms with research sponsorship and those with GMOs that employed novel technologies were more likely than others to garner farm association support. Additionally, t-tests showed that non-foreign firms were more likely than foreign firms to request an FDA consultation. These analyses demonstrate that firms with potentially risky attributes and products are not less likely to mobilize stakeholder and peer agency support. In order to account
} 
associations, we included a count variable (powerful-stakeholder requests) equal to the number of letters the USDA received from farm associations requesting product approval. Each letter represented a particular farm association. We measured positive information from a peer agency with a binary variable indicating whether the product received an FDA memorandum letter (peer-agency memorandum). We read all FDA consultation memoranda and found them to consist of a standard form letter declaring the GMO nutritional labeling acceptable. We obtained information on farm association requests and FDA consultations from the USDA and FDA, respectively.

In keeping with prior research, we measured congressional electoral competitiveness using Congressional Quarterly's forecasts for Senate and House contests (Franklin, 1991; Koch, 1998). Previous studies have found that competitiveness increases congressional responsiveness to the public interest and stimulates legislative action on issues (Skocpol \& Finegold, 1982; Hill et al., 1995). The competitiveness measure is a 4-point variable: 0 indicates a safe seat, 1 that a particular candidate is favored, 2 that the race is leaning toward a particular candidate, and 3 that there is no clear favorite. We averaged all Senate and House races to create a composite yearly score.

We measured GMO protests following previous research (King, 2008) by summing the annual number of protests against GMOs reported in local and national U.S. newspapers using the Lexis-Nexis newspaper database. Prior research has demonstrated that protests often attract public attention, which can in turn engage wider audiences (King \& Soule, 2007; Weber, Rao, \& Thomas, 2009; Ingram, Yue \& Rao, 2010). We believe that this is a reliable measurement that captures the potential of protesters to gain support among various audiences; protests that receive

for any unmeasured heterogeneity that could affect a company's decision to seek farm association and peer agency memoranda, we included firm fixed effects in the analysis. 
no media attention are apt to be invisible to the broader public and thus to have little effect on rallying sympathizers. ${ }^{3}$

We measured whether the petitioning firm was of non-U.S. origin using a dummy variable (foreign company). We measured novel technology using a binary variable to represent whether the genetic transformation used to create a GMO was fundamentally different from that of a previously approved organism. The USDA records this information in its registry of GMO petitions.

Firm-level control variables. Given that larger firms are likely to command both greater resources and greater power to affect regulatory decisions (Stigler, 1971; Carpenter, 2004), we controlled for firm size, defined as number of employees (Hiatt \& Sine, 2013). We also controlled for a firm's technological prestige using patent-citation relationships (Stuart, 1998). Patent applicants often list similar prior inventions to demonstrate the uniqueness of their own inventions (Gittelman \& Kogut, 2003). Such a citation implicitly acknowledges the importance of the cited organization's patent. Thus, firms frequently cited for their agriculturalbiotechnology patents should enjoy higher status in the agricultural-biotechnology domain. We define technological prestige as

$$
\mathrm{D}_{\mathrm{it}}=\sum_{\mathrm{j}} \mathrm{C}_{\mathrm{jit}} / \mathrm{L}_{\mathrm{t}}
$$

where $D_{i t}$ is the prestige of firm $i$ at time $t, C_{j i t}$ is coded as 1 when a patent of firm $j$ cites a patent of firm $i$ during time interval $t$, and $\mathrm{L}_{\mathrm{t}}$ is the total number of patent citations of all agriculturalbiotechnology firms during interval t. Because product lifecycles in the agriculturalbiotechnology realm are similar to those in the larger biotechnology domain, $\mathrm{D}_{\mathrm{it}}$ was computed over a five-year moving window (Stuart, 1998). Given that a biotechnology company's past

\footnotetext{
${ }^{3}$ In Lipsky's words (1968: 1151): "If protest tactics are not considered significant by the media, . . protest organizations will not succeed. Like a tree falling unheard in the forest, there is no protest unless protest is perceived and projected."
} 
approval record can provide information about its ability to produce products that meet the USDA's requirements, we included the number of GMO petitions that failed to receive approval (failed petitions). Finally, to control for any unobserved company characteristics, we included firm fixed effects.

Product-level control variables. When USDA scientists are trying to determine whether a GMO created from extensively studied technologies presents a hazard to the environment, they may consult studies of similar gene transformations published in scientific journals. We thus controlled for cumulative scientific evidence of gene transformations (total scientific journal publications). Using the Institute for Scientific Information's bibliographic software, we searched for articles in scientific journals on each gene transformation reported in the 113 petitions and summed all those articles over time to create a variable that captured all articles published on a given gene transformation by year (e.g., Agrobacterium-EPSPS).

Because the tenor of journal articles may affect the USDA's decision-making (Bednar, 2012), we controlled for the tenor of journal publications for those journal articles that discussed both the particular gene transformation and the particular plant species in question (e.g., Agrobacterium-EPSPS + Corn) using the Janis-Fadner coefficient of imbalance (Deephouse, 2000; Janis \& Fadner, 1965; Pollock \& Rindova, 2003). The measure was calculated using the formula

$$
\text { Tenor }=\left(\mathrm{P}^{2}-\mathrm{PN}\right) / \mathrm{V}^{2} \text { if } \mathrm{P}>\mathrm{N} ; 0 \text { if } \mathrm{P}=\mathrm{N} \text {; and }\left(\mathrm{PN}-\mathrm{N}^{2}\right) / \mathrm{V}^{2} \text { if } \mathrm{N}>\mathrm{P} \text {, }
$$
where $\mathrm{P}$ is the number of positive articles about a gene transformation of a particular plant, $\mathrm{N}$ is the number of negative articles about it, and $\mathrm{V}$ is the total number of articles about it, including those that are neutral. The range of this variable is -1 to 1 where -1 signifies all-negative coverage and 1 signifies all-positive coverage. Following previous research (Pollock \& Rindova, 
2003), each paragraph of a given journal article was coded as positive, negative, or neutral in tenor. If an article contained relatively equal numbers of positive and negative references to a gene transformation's effectiveness and externalities, it was coded as neutral. One of the authors and two research assistants coded all 866 product-specific journal publications.

The more field tests a firm conducts on a new GMO, the greater the positive effect should be on USDA approval: the agency will have more information with which to determine consumer health and environmental safety. We thus included a variable for the number of field trials conducted on a GMO (GMO field tests) and another variable for the number of years it was under examination (GMO testing time). GMOs containing plant-incorporated protectants (pesticides) must be monitored by the Environmental Protection Agency (EPA) after USDA approval. The USDA's guide to the petition process (USDA, 1996) states that the EPA does not review GMOs until after the USDA makes a decision, and in our research we found no information on communication between the USDA and the EPA prior to the USDA's decision. However, to control for any unmeasured effects that this handoff process may have on USDA decision making, we included a dummy variable for plant-incorporated protectants.

We also controlled for whether or not a petition contained confidential business information, as indicated in the USDA's registry of GMO petitions, using a dummy variable. Because numerous GMO petitions can produce a traffic jam, slowing the regulatory approval process, we controlled for the total number of petitions under review at any given time (GMO submission density). Finally, because it requires more time to review a GMO that embodies multiple trait transformations, we controlled for the number of phenotype traits (phenotype variety) using a count variable. ${ }^{4}$

\footnotetext{
${ }^{4}$ We also ran analyses with 10 phenotype categorical variables and found that no individual category, or the interactions of these categories with predictor variables (e.g., herbicide tolerance, insect resistance, etc.), had a
} 
Public-interest control variables. We included a number of variables to control for the political context and advocacy for the public interest. Because the political orientation of elected officials can affect how they supervise government agencies like the USDA, we controlled for the relative conservatism of Congress (congressional conservatism) by averaging the annual ratings of U.S. senators and representatives compiled by the American Conservative Union (ACU). The ACU is the oldest conservative lobbying organization in the country, and its ratings have been used in prior research to measure legislators' adherence to conservative ideologies (Poole \& Daniels, 1985; Hill, Hanna, \& Shafqat, 1997). The ACU's individual ratings are based on the percentage of votes a representative or senator makes in accordance with ACU positions.

We controlled for public advocacy in opposition to GMO approval by including consumer-group concerns about GMOs. We measured consumer-group concerns about GMOs by tallying the number of letters that consumer groups sent to the USDA urging disapproval. We obtained this information from the USDA. Consumer-group opposition may influence the USDA's decision making by providing information on stakeholders who could potentially challenge the agency's legitimacy.

We also controlled for public advocacy in support of GMO approval. Given the powerful role the USDA plays in approving GMOs, agricultural-biotechnology companies have strong incentives to influence USDA decision making using direct tactics, such as lobbying political officials, framing the public discourse through the media, and sponsoring scientific research. Consequently, we included a number of these direct firm influence tactics in our analyses. First, we controlled for firm lobbying of elected officials by summing annual company campaign donations to U.S. senators and members of the House between 1999 and 2007. Because this

significant impact on approval decisions, suggesting that regulatory scrutiny did not vary with specific genetic changes. 
variable was not significant and was limited to only half of the years covered in our study (Congress began collecting this information in 1999), we omitted it from the final analysis.

Second, firms have strong incentives to shape public opinion of their products by promoting favorable news coverage through press releases. Prior research has found that media coverage can significantly affect public opinion on firms' actions (Pollock \& Rindova, 2003; Pollock, Rindova, \& Maggitti, 2008). Hence, we controlled for a firm's public advocacy in favor of GMO approval by counting the number of press releases that biotechnology firms generate about products they submit for USDA approval (firm press releases). We counted in the pressrelease database of Lexis-Nexis all press releases to journalists, by firm and product, leading up to a GMO approval decision found.

Finally, we controlled for corporate authorship and sponsorship of research studies supporting GMO approval (journal publications sponsored by firm). Prior research has found that firms promote publication of their innovations in academic journals to facilitate assessment by regulatory agencies (Polidoro \& Theeke, 2012). We identified every scientific journal article that listed an author from a biotechnology company or referred to corporate provision of data or project sponsorship. We then summed all sponsored articles with positive tenor by productspecific gene transformation.

\section{Analysis}

We employed an event-history analysis to investigate the effects of stakeholder and peeragency product assessments on the rate of petition approval by the USDA. We used a Cox proportional hazards model because, unlike parametric regression models, it does not require assumptions about the shape of the baseline hazard, resulting in greater flexibility. The hazard rate is given as 


$$
\mathrm{h}_{i}(\mathrm{t})=\mathrm{h}_{0}(\mathrm{t}) \exp \left(\beta^{\prime} \chi\right)
$$

where $\mathrm{h}_{0}(\mathrm{t})$ is the baseline hazard function and $\beta^{\prime} \chi$ are the covariates and unknown regression parameters. We included organizational fixed effects to control for any unmeasured heterogeneity. Some of our variables were highly correlated, which can lead to inflated standard errors and unstable regression coefficients. We created a synthetic instrument using a GramSchmidt procedure to partial out the common variance between the highly correlated variables (Cohen \& Cohen, 1983). We then tested for multicollinearity and found that all variance-inflation factors in the event-history analysis were less than 4.97, and that the majority were less than 2.35 , indicating an acceptable level of multicollinearity (Afifi, Clark, \& May, 2004).

\section{RESULTS}

Descriptive statistics and bivariate correlations appear in Table 1; the results of the Cox hazard model predicting the rate of GMO product approval appear in Table 2. In the latter table, model 1 shows the effects of the control variables only; model 2 adds approval requests from powerful stakeholders (e.g., farm association approval requests); model 3 adds a memorandum from a peer agency (e.g., FDA consultation); model 4 includes the interaction between powerfulstakeholder requests and congressional electoral competitiveness; model 5 adds the interaction between powerful-stakeholder requests and GMO protests; model 6 adds the interaction between peer-agency memorandum and foreign company; model 7 includes the interaction between peeragency memorandum and novel technology; and model 8 includes all the independent variables and their interactions.

---Insert Table 1 and Table 2 about here---

Several control variables had a significant effect on product-approval rates. The petitionapproval rate was lower for companies with a history of failed product submissions. It was also 
lower for foreign companies, suggesting that development and testing under non-U.S. standards increased concerns about a GMO’s safety. Novel technology, congressional electoral competitiveness, and GMO protests also reduced approval rates, consistent with our predictions. ${ }^{5}$ The tenor of journal publications also had a negative impact on approval rate. The latter effect may be due in part to firm sponsorship of journal articles: nearly 53 percent of articles with a positive tenor were sponsored by biotechnology companies. This high rate of corporate sponsorship may cause the USDA to discount positive-tenor publications in its decision making (Trumbull, 2012). Other direct forms of political influence, such as lobbying by political officials and advocacy via press releases, did not have a significant effect on agency decision making.

All of our hypotheses were supported. ${ }^{6}$ Our results provide strong support for Hypothesis 1, which predicts that approval requests from powerful stakeholders (e.g., farm association approval requests) would increase the rate of regulatory approval. Model 2 , for example, shows that GMOs are two and a half times more likely to get approval when they have farm association support. ${ }^{7}$ Our results also provide strong support for Hypothesis 2, which posits that a positive memorandum from a peer agency (e.g., FDA consultation) increases the rate of regulatory approval. Model 3 shows that GMOs are more than five times likely to be approved when accompanied by a positive FDA memorandum.

Hypotheses 3 and 4 suggest that the influence of powerful stakeholders will increase with greater external threats to legitimacy. Hypothesis 3 predicts that the effect of influential stakeholders will be greater if congressional electoral competitiveness is high. Model 4 shows

\footnotetext{
${ }^{5}$ In analyses not reported here, we found that greater congressional competitiveness had a significant negative impact on USDA budget outlays and yearly changes in budget outlays, suggesting that competitive races can increase congressional scrutiny of government agency resources.

${ }^{6} \mathrm{We}$ also ran the analysis without the 12 petitions awaiting a decision and found no significant difference in the results.

${ }^{7}$ The risk of approval, or hazard ratio, is derived by exponentiating the coefficients.
} 
that GMOs are more than one and a half times more likely to be approved when farm association approval requests occur under conditions of high electoral competitiveness, providing support for Hypothesis 3 (see Figure 2). Hypothesis 4 predicts that the effect of powerful stakeholders will be greater in the presence of GMO protests. According to Model 5, GMOs are one and a half times more likely to be approved when farm association requests occur during GMO protests, providing support for Hypothesis 4.

Hypotheses 5 and 6 suggest that the influence of peer agencies' memoranda will increase with internal threats to legitimacy. Models 6 and 7 generally support these hypotheses. Hypothesis 5 predicts that a positive memorandum from a peer agency will have a greater positive effect on the rate of regulatory approval for firms of non-U.S. origin. According to Model 6, GMOs are fifteen times more likely to be approved for foreign companies that receive a positive FDA memorandum (see Figure 3). Model 7 supports Hypothesis 6, which predicts that a memorandum from a peer agency will have a greater effect when a biotechnology product is novel; GMOs are more than nine times more likely to be approved for novel transgenic products that receive a positive FDA memorandum. T-tests comparing the frequency of FDA memorandum requests indicated that, whereas firms with novel products were no more likely to request peeragency consultations, non-foreign firms were more likely to request consultations than foreign companies; this suggests that foreign firms may be disadvantaged in understanding the regulatory process and which actors could benefit their petitions. Model 8 shows that all interactions are statistically significant net of each other.

\section{DISCUSSION AND CONCLUSION}

This article examines a question seldom addressed by prior work on businessgovernment relations, but critical to understanding those relations: What factors shape the 
decision making of government agencies? The paucity of studies that answer this question is a serious omission given that regulatory agencies are the government actors most in contact with businesses through day-to-day interpretation and execution of laws. Our paper brings regulatory agencies center stage, and reveals an interesting answer: In the process of managing legitimacy risk, regulatory agencies are influenced by the assessments of third-party actors, namely, powerful stakeholders and peer agencies, which serve as protective shields against various threats to legitimacy.

We have also offered evidence that the mechanisms whereby third-party actors influence regulatory agencies are differentiated. The results show that the influence of approval requests from farm associations increases with greater external risks flowing from competitive congressional races and collective protests; the influence of positive memoranda from a peer agency increases with greater internal risks from the product and producer. In models not shown here, we found that the effect of third-party influence varied only with the level of external or internal risks: the influence of powerful stakeholders increased with external risks but not with internal risks. In contrast, peer-agency influence increased with internal, but not with external, risks. The results also suggest that internal risks increased the USDA's reliance on third-party assessments much more than external risks. This effect is not surprising given the USDA's history of jurisdictional and resource expansion. Much of the agency's growth has been due in large part to its longstanding commitment to, and competence in, science, food safety, and the environment (Gauss, Wolcott, \& Lewis, 1940); hence it would be more particularly concerned with managing its procedural legitimacy.

A couple of limitations worth noting are that we were not able to control for all possible direct influence tactics of biotechnology firms, and that we only analyzed genetically modified 
plant (not animal) organisms. Our analyses partially address these shortcomings by controlling for the most prevalent firm tactics researched in the regulatory-capture literature, and for the phenotype characteristics that could differentially affect the health of animals and humans. It would certainly be valuable for future research to understand firm influence tactics more comprehensively, and consider how particular products (e.g., GMOs, pharmaceutical drugs) may compel certain important stakeholders in the environment to influence agency decision making.

Our study makes several important contributions. In particular, our focus on regulatory agencies and third parties has profound consequences for research on business-government relations. First, our study reveals the understudied role of regulatory agencies (Bonardi et al., 2005). Given that regulatory agencies are the government agencies that have the most contact with businesses, it is surprising how little is known about their operations (Holburn \& Vanden Bergh, 2002). We fill that vacuum by examining agency decision making that can have a critical impact on firm performance. Second, our study focuses on the influence of third-party actors on regulatory decisions, portraying regulatory agencies not merely as discrete economic entities, but as social actors striving to maintain legitimacy and maximize autonomy (Skocpol, 1985;

Whetten, 2006; King et al., 2010). Prior research has often treated business-government relations as merely asocial dyadic exchanges in a marketplace in which policy demanders and suppliers transact over regulatory decisions (Hillman \& Keim, 1995; Bonardi et al., 2005; Jia, forthcoming). For example, studies guided by the idea of regulatory capture suggest that elected politicians shape regulatory policy in exchange for resources from organized interest groups in order to remain in office (Stigler, 1971). This conventional approach, though insightful, ignores the important roles of legitimacy and social influence in government agency decision making. In contrast, our study enriches the simplistic imagery of regulators as economic actors, and suggests 
that future business-government relations literature would benefit from a more nuanced approach that goes beyond asocial exchanges between regulators and those they regulate.

Our findings on the contingent influence of powerful stakeholders also offer a much needed answer to a key question in stakeholder theory: Under what conditions do stakeholder interests matter more? Although scholars have highlighted the general importance of stakeholders in various contexts (e.g., Gargiulo, 1993; Rowley, 1997; Mitchell, Agle, \& Wood 1997; Eesley \& Lennox, 2006; Bansal \& Hoffman, 2012; Vasi \& King, 2012), there has been little empirical research examining the political conditions that amplify or reduce stakeholder impact. Our paper extends current stakeholder theory by demonstrating how the influence of stakeholders can be moderated by participation in political tactics like protests, and by political environments, such as competitive congressional elections, that can amplify their voice among elected officials (King \& Pearce, 2010). Unlike previous studies that have focused exclusively on the impact of stakeholders on firms, this study finds that stakeholders can also exert influence in the regulatory realm by affecting regulatory agency decision processes. By differentiating the influences of various audiences and constituencies on two different types of legitimacy, our study also responds to the call for research on the effects of heterogeneous stakeholders and contributes to "the development of a more generalizable theory of intangible assets based on social approval" (Pfarrer, Pollock, \& Rindova, 2010: 1146). Future research will be advanced by considering how multiple stakeholders affect and are affected by each other, and how such interdependencies amplify or constrain their influence on players in the political realm who strive to maintain and increase legitimacy and other immaterial assets.

This study also deepens our understanding of government agencies. Neo-institutional theory, with its open-systems approach and strong focus on the environment, has been criticized 
for treating government agencies as an exogenous coercive force that constrains organizations merely to conform to formal institutions, thereby downplaying agency and intentionality on the part of the firm and the state (Skocpol, 1985; Hirsch \& Lounsbury, 1997; Hiatt, Sine, \& Tolbert, 2009; Marquis and Huang, 2009; King, et al., 2010; for an exception, see Edelman \& Suchman, 1997). Our study offers a partial answer to this criticism by showing how the USDA has been relatively successful at preserving its autonomy and legitimacy in spite of various risks. This finding can be applicable to government agencies in general, setting the stage for future research on agency among state institutions, and on the role of government agencies in the implementation of policy. For example, fruitful avenues of research include exploring how government agency discretion and variation in policy implementation affect the emergence and adoption of new organizational forms and technologies (Tushman \& Anderson, 1986; Henderson \& Clark, 1990). Others include examining the effects of such variation on the propensity of government agencies to influence and be influenced by actors in the environment, thereby contributing to studies on public and private politics (Mizruchi, 1989, 1992; Reid \& Toffel, 2009).

This paper also contributes to the strategic management literature by suggesting how firms in highly regulated environments can pursue political or nonmarket strategies to influence regulatory decision making (Shaffer \& Hillman, 2000; Davis, 2005; Lee, 2009). Prior research contributed to our conceptual understanding of the importance of government policy to firm performance and the circumstances in which firms engage in political strategies (Fligstein, 1996; Dobbin \& Dowd, 1997; Hillman \& Hitt, 1999). For example, scholars have explored how firms reacted to variation in their political environments (e.g., Henisz \& Delios, 2001; King \& Shaver, 2001), but very few have empirically examined how firms can influence government agency 
decision making (Hillman \& Keim, 1995). Although our focus is on a regulatory agency rather than on a regulated firm, the current study stands to contribute to this line of research by suggesting that regulatory agencies' preoccupation with legitimacy creates conditions in which firms can influence regulatory decision making by capturing the third-party actors regulatory agencies rely on to manage their risk, in this case, powerful stakeholders and peer agencies. Through farm associations, biotechnology firms direct farmers to GMO products in the pipeline, arrange for meetings with farmers, and coordinate farmer advocacy and support programs for their products (e.g., Monsanto's America's Farmers campaign). Through FDA product consultations, biotechnology firms obtain a relatively low-cost certification of their products' safety. By describing the mechanisms whereby companies can indirectly influence regulatory outcomes, we offer a richer understanding of nonmarket strategy and its impact on firm performance.

Finally, our study clearly has significant managerial implications for firms in regulated industries. The agricultural-biotechnology firms in our study that gained external support from farm associations received approval decisions about 162 days sooner than average, and those firms that held labeling consultations with the FDA shaved about 257 days off the average wait. This is consequential: it can cost a biotechnology firm up to $\$ 2$ million in forgone revenue for each day its product is under review rather than on the market (Monsanto, 2010). Increasing utilization of third-party influence on the part of some biotechnology firms suggests that certain companies understand that these strategies are working. We believe that implementation of this influence tactic is also feasible in other regulated domains, such as the public utility, oil and gas, and pharmaceutical sectors (Carpenter, 2001; Sine et al., 2005). In such sectors, firms will have at their disposal not just direct tools like lobbying and expert testimony, but also indirect tools, 
such as connections to influential third parties. It will be an important direction for future research and practice to investigate the relationships among these tactics, and to distinguish their relative importance. 


\section{REFERENCES}

Afifi, A. A., Clark, V. A., \& May, S. 2004. Computer-Aided Multivariate Analysis. Boca Ratón, Fla.: Chapman \& Hall/CRC.

Animal and Plant Health Inspection Service (APHIS). 2005. Final EA \& Determination \#01137-01p. Washington, DC: U.S. Department of Agriculture.

Bansal, P., \& Hoffman, A. J. (Eds.). 2012. The Oxford Handbook of Business and the Natural Environment. New York: Oxford University Press.

Bednar, M. 2012. Watchdog or lapdog? A behavioral view of the media as a corporate governance mechanism. Academy of Management Journal, 55: 131-150.

Besley, T., \& Burgess, R. 2002. The political economy of government responsiveness: Theory and evidence from India. Quarterly Journal of Economics, 117(4): 1415-1451.

Bonardi, J.-P., Hillman, A. J., \& Keim, G. D. 2005. The attractiveness of political markets: Implications for firm strategy. Academy of Management Review, 30(2): 397-413.

Carpenter, D. P. 2001. The Forging of Bureaucratic Autonomy: Reputations, Networks, and Policy Innovation in Executive Agencies, 1862-1928. Princeton, NJ: Princeton University Press.

Carpenter, D. P. 2002. Groups, the media, agency waiting costs, and FDA drug approval. American Journal of Political Science, 46(2): 490-505.

Carpenter, D. P. 2004. Protection without capture: Product approval by a politically responsive, learning regulator. American Political Science Review, 98(4): 613-631.

Charles, D. 2001. Lords of the Harvest: Biotech, Big Money, and the Future of Food. Cambridge, MA: Perseus.

Clarkson, M. E. 1995. A stakeholder framework for analyzing and evaluating corporate social responsibility. Academy of Management Review, 20: 92-117.

Cohen, J., \& Cohen, P. 1983. Applied Multiple Regression/Correlational Analysis for the Behavior Sciences. Hillsdale, NJ: Lawrence Erlbaum.

Conner, A. J., Glare, T. R., \& Nap, J. P. 2003. The release of genetically modified crops into the environment. Plant Journal, 33: 19-46.

Dal Bó, E. 2006. Regulatory capture: A review. Oxford Review of Economic Policy, 22(2): 203 225.

Davis, G. 2005. Firms and environments. In N. Smelser, \& R. Swedberg (Eds.), The Handbook of Economic Sociology. New York: Princeton University Press.

Deephouse, D. L. 2000. Media reputation as a strategic resource: An integration of mass communication and resource-based theories. Journal of Management, 26(6): 1091-1112.

Deephouse, D. L. \& Suchman, M. 2008. Legitimacy in organizational institutionalism. In R. Greenwood, C. Oliver, R. Suddaby, \& K. Sahlin (Eds.), The Sage Handbook of Organizational Institutionalism. Sage: Thousand Oaks, CA: 49-77.

Delmas, M., \& Toffel, M. W. 2004. Stakeholders and environmental management practices: An institutional framework. Business Strategy and the Environment, 13: 209-222.

Dobbin, F. R., \& Dowd, T. J. 1997. How policy shapes competition: Early railroad foundings in Massachusetts. Administrative Science Quarterly, 42(3): 501-529. 
Edelman, L. B., \& Suchman, M. C. 1997. The legal environments of organizations. Annual Review of Sociology, 23: 479-515.

Eesley, C., \& Lenox, M. J. 2006. Firm responses to secondary stakeholder action. Strategic Management Journal, 27(8): 765-781.

Eisenhardt, K. M., \& Zbaracki, M. J. 1992. Strategic decision making. Strategic Management Journal, 13: 17-37.

Fischer, H. M., \& Pollock, T. G. 2004. Effects of social capital and power on surviving transformational change: The case of initial public offerings. The Academy of Management Journal, 47(4): 463-481.

Fligstein, N. 1996. Markets as politics: A political-cultural approach to market institutions. American Sociological Review, 61(4): 656-673.

Franklin, C. H. 1991. Eschewing obfuscation? Campaigns and the perception of U.S. Senate incumbents. American Political Science Review, 85(4): 1193-1214.

Garcia-Canal, E., \& Guillen, M. F. 2008. Risk and the strategy of foreign location choice in regulated industries. Strategic Management Journal, 29: 1097-1115.

Gargiulo, M. 1993. Two-step leverage: Managing constraint in organizational politics. Administrative Science Quarterly, 38(1): 1-19.

Gaus, J. M., Wolcott, L. O., \& Lewis, V. B. 1940. Public Administration and the United States Department of Agriculture. Chicago: Published for the Committee on Public Administration of the Social Science Research Council by Public Administration Service.

Gittelman, M., \& Kogut, B. 2003. Does good science lead to valuable knowledge? Biotechnology firms and the evolutionary logic of citation patterns. Management Science, 49(4): 366-382.

Hails, R. S., \& Morley, K. 2005. Genes invading new populations: A risk assessment perspective. Trends in Ecology and Evolution, 20: 245-252.

Henderson, R. M., \& Clark, K. B. 1990. Architectural innovation: The reconfiguration of existing product technologies and the failure of established firms. Administrative Science Quarterly, 35(1): 9-30.

Henisz, W. J., \& Delios, A. 2001. Uncertainty, imitation, and plant location: Japanese multinational corporations, 1990-1996. Administrative Science Quarterly, 46(3): 443-475.

Hiatt, S. R. \& Sine, W. D. 2013. Clear and present danger: Planning and new venture survival amid political and civil violence. Strategic Management Journal, forthcoming.

Hiatt S. R., Sine W. D., \& Tolbert P. S. 2009. From Pabst to Pepsi: The deinstitutionalization of social practices and the creation of entrepreneurial opportunities. Administrative Science Quarterly, 54: 635-667.

Hill, K. Q., Hanna, S., \& Shafqat, S. 1997. The liberal-conservative ideology of U.S. senators: A new measure. American Journal of Political Science, 41(4): 1395-1413.

Hill, K. Q., Leighley, J. E., \& Hinton-Andersson, A. 1995. Lower-class mobilization and policy linkage in the U.S. states. American Journal of Political Science, 39(1): 75-86.

Hillman, A. J., \& Hitt, M. 1999. Corporate political strategy formulation: A model of approach, participation, and strategy decisions. Academy of Management Review, 24(4): 825-842. 
Hillman, A. J., \& Keim, G. D. 1995. International variation in the business-government interface: Institutional and organizational considerations. Academy of Management Review, 20: 193-214.

Hirsch, P. M., \& Lounsbury, M. 1997. Putting the organization back into organization theory. Journal of Management Inquiry, 6(1): 79-88.

Holburn, G. L. F., \& Vanden Bergh, R. G. 2002. Policy and process: A game-theoretic framework for the design of non-market strategy. In P. Ingram, \& B. Silverman (Eds.), Advances in Strategic Management, 19: 33-66.

Hooks, G. 1990. From an autonomous to a captured state agency: The decline of the New Deal in agriculture. American Sociological Review, 55(1): 29-43.

Ingram, P. Yue, L., \& Rao, H. 2010. Trouble in store: The emergence and success of protests against Wal-Mart store openings in America. American Journal of Sociology, 116: 53-92.

International Food Information Council (IFIC). 2007. Food Biotechnology: Enhancing our Food Supply. Washington, DC.

Jacob, M., \& Hellstrom, T. 2000. Policy understanding of science, public trust and the BSE-CJD crisis. Journal of Hazardous Materials, 78: 303-317.

Janis, I. L., \& Fader, R. 1965. The coefficient of imbalance. In H. Lasswell, N. Leites, \& Associates (Eds.), Language of Politics. Cambridge, MA: MIT Press.

Jia, N. forthcoming. Are collective and private political actions substitutes or complements? Empirical evidence from China's private sector. Strategic Management Journal.

King, A. A., \& Shaver, J. M. 2001. Are aliens green? Assessing foreign establishments' environmental conduct in the United States. Strategic Management Journal, 22: 1069-1085.

King, B. G. 2008. A political mediation model of corporate response to social movement activism. Administrative Science Quarterly, 53(3): 395-421.

King, B. G., Felin, T., \& Whetten, D. 2010. Finding the organization in organizational theory: A meta-theory of the organization as a social actor. Organization Science, 21: 290-305.

King, B. G., \& Pearce, N. 2010. The contentiousness of markets: Politics, social movements, and institutional change in markets. Annual Review of Sociology, 36: 249-267.

King, B. G., \& Soule, S. A. 2007. Social movements as extra-institutional entrepreneurs: The effect of protests on stock price returns. Administrative Science Quarterly, 52(3): 413-442.

Koch, J. W. 1998. Electoral competitiveness and the voting decision evidence from the pooled Senate election study. Political Behavior, 20(4): 295-311.

Knowles, T., Moody, R., \& McEarchern, M. G. 2007. European foods scares and their impact on EU food policy. British Food Journal, 109(1): 43-67.

Lee, B. H. 2009. The infrastructure of collective action and policy content diffusion in the organic food industry. Academy of Management Journal, 52: 1247-1269.

Lipsky, M. 1968. Protest as a political resource. American Political Science Review, 62(4): 1144-1158.

McConnell, G. 1953. The Decline of Agrarian Democracy. Berkeley: University of California Press.

McNeil, D. G. 2006. Study suggests more deaths from mad cow disease. New York Times, 23 June 2006. 
Marquis, C \& Huang, Z. 2009. The contingent nature of public policy and the growth of U.S. commercial banking. Academy of Management Journal, 52: 1222-1246.

Miner, A. S., Amburgey, T. L., \& Stearns, T. M. 1990. Interorganizational linkages and population dynamics: Buffering and transformational shields. Administrative Science Quarterly, 35(4): 689-713.

Mitchell, R. K., Agle, B. R., \& Wood, D. J. 1997. Toward a theory of stakeholder identification and salience: Defining the principles of who and what really counts. Academy of Management Review, 22: 853-886.

Mizruchi, M. S. 1989. Similarity of political behavior among large American corporations. American Journal of Sociology, 95(2): 401-424.

Mizruchi, M. S. 1992. The Structure of Corporate Political Action. Cambridge, MA: Harvard University Press.

Monsanto. 2010. Supplemental Toolkit for Investors. St. Louis, MO: Monsanto Company.

Mueller, D. C. 2003. Public Choice III. New York: Cambridge University Press.

Niskanen, W. A. 1971. Bureaucracy and Representative Government. New Brunswick, NJ: Aldine Transaction.

North, D. C. 1990. Institutions, Institutional Change and Economic Performance. Cambridge, UK: Cambridge University Press.

Olson, M. K. 1997. Firm characteristics and the speed of FDA approval. Journal of Economics \& Management Strategy, 6(2): 377-401.

Peretti, J. 2004. The Nike sweatshop email: Political consumerism, internet, and culture jamming. In M. Micheletti, A. Føllesdal, \& D. Stolle (Eds.), Politics, Products, and Markets: Exploring Political Consumerism Past and Present. New Brunswick, NJ: Transaction Publishers.

Pfarrer, M. D, Pollock, T. G., \& Rindova, V. P. 2010. A tale of two assets: The effects on firm reputation and celebrity on earnings surprises and investors' reactions. Academy of Management Journal, 53(5): 1131-1152.

Pfeffer, J., \& Salancik, G. R. 1978. The External Control of Organizations. New York: Harper \& Row.

Polidoro, F., \& Theeke, M. 2012. Getting competition down to a science: The effects of technological competition on firms' scientific publications. Organization Science, 23(4): 1135-1153.

Pollock, T. G., \& Rindova, V. P. 2003. Media legitimation effects in the market for initial public offerings. Academy of Management Journal, 46: 631-646.

Pollock, T. G., Rindova, V. P., \& Maggitti, P. G. 2008. Market watch: Information and availability cascades among the media and investors in the US IPO market. Academy of Management Journal, 51(2): 335-358.

Poole, K. T., \& Daniels, R. S. 1985. Ideology, party, and voting in the U.S. Congress, 19591980. American Political Science Review, 79(2): 373-399.

Reid, E. M., \& Toffel, M. W. 2009. Responding to public and private politics: Corporate disclosure of climate change strategies. Strategic Management Journal, 30(11): 1157-1178.

Rivers, T. 2007. Britain hit by another food-and-mouth disease scare. Voice of America News, 4 August. 
Rowley, T. J. 1997. Moving beyond dyadic ties: A network theory of stakeholder influences. Academy of Management Review, 22(4): 887-910.

Sabatier, P., \& Mazmanian, D. 1980. The implementation of public policy: A framework of analysis. Policy Studies Journal, 8(4): 538-560.

Scott, W. R. 1992. Organizations: Rational, Natural, and Open Systems. Englewood Cliffs, NJ: Prentice Hall.

Shaffer, B., \& Hillman, A. J. 2000. The development of business-government strategies by diversified firms. Strategic Management Journal, 21: 175-190.

Sine, W. D., Haveman, H. A., \& Tolbert, P. S. 2005. Risky business? Entrepreneurship in the new independent-power sector. Administrative Science Quarterly, 50(2): 200-232.

Skocpol, T. 1985. Bringing the state back in: Strategies for analysis in current research. In P. Evans, D. Rueschemeyer \& T. Skocpol (Eds.), Bringing the State Back In. New York: Cambridge University Press, 3-43.

Skocpol, T., \& Finegold, K. 1982. State capacity and economic intervention in the early New Deal. Political Science Quarterly, 97(2): 255-278.

Soule, S. A., \& King, B. G. 2006. The stages of policy process and the equal rights amendment, 1972-1982. American Journal of Sociology, 111(6): 1871-1909.

Soule, S. A., \& Olzak, S. 2004. When do movements matter? The politics of contingency and the Equal Rights Amendment. American Sociological Review, 69: 473-497.

Stigler, G. J. 1971. The theory of economic regulation. Bell Journal of Economics and Management Science, 2(1): 3-21.

Stuart, T. E. 1998. Network positions and propensities to collaborate: An investigation of strategic alliance formation in a high-technology industry. Administrative Science Quarterly, 43(3): 668-698.

Suchman, M. C. 1995. Managing legitimacy: Strategic and institutional approaches. Academy of Management Review, 20(3): 571-610.

Thornton, P. H., \& Ocasio, W. 2008. Institutional logics. In R. Greenwood, C. Oliver, K. Sahlin, \& R. Suddaby (Eds.), The SAGE Handbook of Organizational Institutionalism. Thousand Oaks: Sage Publications: 99-129.

Trumbull, J. G. 2012. Strength in Numbers: The Power of Weak Interests. Cambridge, MA: Harvard University Press.

Tushman, M. L., \& Anderson, P. 1986. Technological discontinuities and organizational environments. Administrative Science Quarterly, 31(3): 439-465.

U.S. Department of Agriculture. 1996. Guide for Preparing and Submitting a Petition for Genetically Engineered Plants. Washington, DC: USDA.

U.S. Department of Agriculture. 2012a, Act to Establish a Department of Agriculture. http://www.nal.usda.gov/act-establish-department-agriculture, [accessed, 4/23/12].

U.S. Department of Agriculture. 2012b, Mission Statement. http://www.usda.gov/wps/portal/usda/usdahome?navid=MISSION_STATEMENT, [accessed, $4 / 23 / 12]$.

Vasi, I. B., \& King, B. 2012. Social movements, risk perceptions, and economic outcomes: The effect of primary and secondary stakeholder activism on firms' perceived environmental risk and financial performance. American Sociological Review, 77: 573-596. 
Weatherby, J. L. 1971. A note on administrative behavior and public policy. Public Choice, 11(1): 107-110.

Weber, K., Rao, H., \& Thomas, L. G. 2009. From streets to suites: How the anti-biotech movement penetrated German pharmaceutical firms. American Sociological Review, 74: 106-127.

Whetten, D. A. 2006. Albert and Whetten revisited: Strengthening the concept of organizational identity. Journal of Management Inquiry, 15: 219-234. 
Table 1. Bivariate Correlations and Descriptive Statistics

\begin{tabular}{|c|c|c|c|c|c|c|c|c|c|}
\hline & Variable & Mean & $\begin{array}{l}\text { Std. } \\
\text { Dev. }\end{array}$ & 1 & 2 & 3 & 4 & 5 & 6 \\
\hline & $\begin{array}{l}\text { GMO approval } \\
\text { Powerful stakeholder influence (Farm }\end{array}$ & 0.324 & 0.469 & & & & & & \\
\hline 1 & $\begin{array}{l}\text { association approval requests) } \\
\text { Peer-agency memorandum (FDA }\end{array}$ & 0.611 & 1.214 & 1 & & & & & \\
\hline 2 & Consultation) & 0.352 & 0.480 & 0.141 & 1 & & & & \\
\hline 3 & Congressional electoral competitiveness & 0.477 & 0.153 & -0.198 & 0.062 & 1 & & & \\
\hline 4 & GMO protests & 8.574 & 12.825 & -0.126 & -0.159 & -0.313 & 1 & & \\
\hline 5 & Foreign company & 0.324 & 0.470 & -0.121 & -0.055 & 0.323 & -0.133 & 1 & \\
\hline 6 & Novel technology & 0.852 & 0.357 & 0.146 & 0.144 & 0.157 & 0.029 & -0.045 & 1 \\
\hline 7 & Failed petitions & 0.245 & 0.235 & -0.095 & 0.076 & 0.297 & -0.627 & -0.065 & -0.071 \\
\hline 8 & Patent citations * 100 & 64.806 & 86.510 & -0.012 & 0.007 & -0.061 & -0.063 & 0.403 & -0.134 \\
\hline 9 & Firm size / 1000 & 19.265 & 24.219 & -0.053 & 0.189 & 0.169 & -0.174 & 0.169 & -0.036 \\
\hline 10 & Confidential business information & 0.250 & 0.435 & 0.044 & 0.246 & -0.005 & -0.401 & -0.034 & 0.000 \\
\hline 11 & GMO field tests & 52.537 & 73.062 & 0.051 & 0.154 & 0.050 & 0.033 & -0.099 & 0.141 \\
\hline 12 & GMO testing time & 3.083 & 1.511 & 0.105 & 0.140 & -0.113 & 0.087 & -0.104 & 0.075 \\
\hline 13 & Total scientific journal publications & 5344 & 6923 & 0.023 & 0.149 & 0.138 & -0.160 & -0.118 & 0.132 \\
\hline 14 & Tenor of journal publications & 0.709 & 0.395 & -0.107 & -0.042 & 0.075 & 0.116 & -0.026 & -0.013 \\
\hline 15 & Journal publications sponsored by firm & 3.074 & 3.395 & 0.223 & -0.119 & -0.109 & 0.056 & -0.115 & -0.230 \\
\hline 16 & Phenotype variety & 1.213 & 0.454 & -0.086 & 0.039 & -0.107 & -0.011 & -0.064 & -0.092 \\
\hline 17 & Plant-incorporated protectants & 0.269 & 0.445 & 0.057 & 0.210 & -0.197 & 0.154 & -0.286 & 0.135 \\
\hline 18 & GMO submission density & 13.611 & 4.954 & -0.358 & 0.038 & -0.055 & 0.525 & -0.062 & 0.009 \\
\hline 19 & Congressional conservatism & 0.489 & 0.041 & -0.037 & 0.128 & 0.255 & -0.287 & -0.126 & -0.131 \\
\hline 20 & Consumer-group concerns about GMOs & 0.454 & 1.403 & 0.291 & 0.011 & -0.166 & -0.062 & 0.030 & -0.163 \\
\hline 21 & Firm press releases & 35.176 & 68.554 & 0.465 & 0.298 & 0.081 & -0.394 & -0.187 & 0.097 \\
\hline
\end{tabular}




\begin{tabular}{|c|c|c|c|c|c|c|c|c|c|c|c|c|c|c|}
\hline & 7 & 8 & 9 & 10 & 11 & 12 & 13 & 14 & 15 & 16 & 17 & 18 & 19 & 20 \\
\hline 7 & 1 & & & & & & & & & & & & & \\
\hline 8 & -0.032 & 1 & & & & & & & & & & & & \\
\hline 9 & 0.225 & -0.087 & 1 & & & & & & & & & & & \\
\hline 10 & 0.369 & 0.010 & 0.294 & 1 & & & & & & & & & & \\
\hline 11 & 0.199 & 0.192 & -0.012 & 0.122 & 1 & & & & & & & & & \\
\hline 12 & 0.013 & 0.092 & -0.015 & 0.082 & 0.407 & 1 & & & & & & & & \\
\hline 13 & 0.265 & -0.054 & 0.023 & 0.190 & 0.399 & 0.318 & 1 & & & & & & & \\
\hline 14 & -0.016 & -0.172 & 0.017 & -0.088 & -0.153 & -0.005 & -0.162 & 1 & & & & & & \\
\hline 15 & 0.011 & -0.153 & 0.038 & -0.114 & -0.078 & 0.050 & 0.149 & 0.240 & 1 & & & & & \\
\hline 16 & 0.016 & 0.014 & 0.076 & -0.036 & 0.096 & 0.137 & 0.193 & 0.135 & 0.123 & 1 & & & & \\
\hline 17 & 0.089 & 0.044 & 0.013 & 0.181 & 0.350 & 0.272 & 0.628 & -0.080 & 0.049 & 0.315 & 1 & & & \\
\hline 18 & -0.426 & 0.051 & -0.107 & -0.262 & 0.006 & 0.044 & -0.029 & 0.121 & -0.049 & 0.021 & 0.154 & 1 & & \\
\hline 19 & 0.517 & 0.031 & 0.160 & 0.238 & 0.261 & 0.010 & 0.069 & -0.046 & -0.091 & -0.082 & 0.013 & -0.078 & 1 & \\
\hline 20 & -0.047 & 0.203 & -0.009 & 0.149 & -0.039 & 0.079 & -0.137 & -0.030 & -0.003 & 0.023 & -0.047 & -0.415 & -0.033 & 1 \\
\hline 21 & 0.255 & -0.117 & -0.068 & 0.165 & 0.393 & 0.148 & 0.245 & -0.169 & 0.053 & -0.114 & 0.073 & -0.289 & 0.289 & 0.114 \\
\hline
\end{tabular}


Table 2. Cox Event-History Regression of GMO Approval Rate

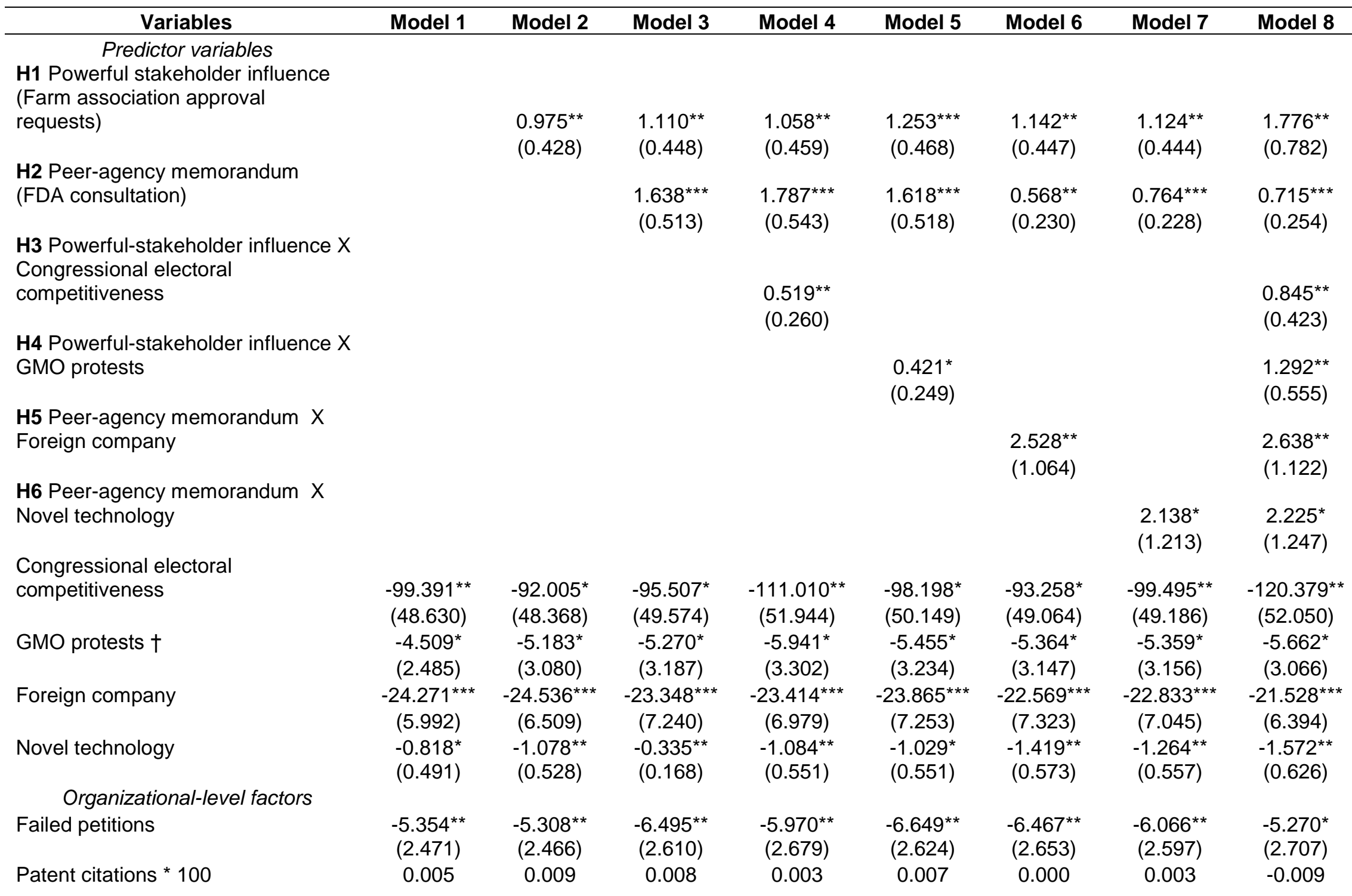




\begin{tabular}{|c|c|c|c|c|c|c|c|c|}
\hline & $(0.017)$ & $(0.018)$ & $(0.019)$ & $(0.019)$ & $(0.020)$ & $(0.020)$ & $(0.020)$ & $(0.020)$ \\
\hline \multirow[t]{2}{*}{ Firm size / 1000} & -0.080 & -0.079 & -0.077 & -0.086 & -0.096 & -0.099 & -0.060 & -0.083 \\
\hline & $(0.115)$ & $(0.116)$ & $(0.121)$ & $(0.124)$ & $(0.124)$ & $(0.124)$ & $(0.119)$ & $(0.124)$ \\
\hline Firm fixed effects & Yes & Yes & Yes & Yes & Yes & Yes & Yes & Yes \\
\hline \multicolumn{9}{|l|}{ Product-level factors } \\
\hline Confidential business information & $\begin{array}{l}-0.001 \\
(0.547)\end{array}$ & $\begin{array}{c}0.153 \\
(0.563)\end{array}$ & $\begin{array}{c}0.435 \\
(0.645)\end{array}$ & $\begin{array}{c}0.389 \\
(0.659)\end{array}$ & $\begin{array}{c}0.431 \\
(0.651)\end{array}$ & $\begin{array}{c}0.535 \\
(0.664)\end{array}$ & $\begin{array}{c}0.387 \\
(0.651)\end{array}$ & $\begin{array}{c}0.321 \\
(0.682)\end{array}$ \\
\hline GMO field tests & $\begin{array}{c}0.003 \\
(0.003)\end{array}$ & $\begin{array}{c}0.004 \\
(0.003)\end{array}$ & $\begin{array}{l}0.006^{*} \\
(0.003)\end{array}$ & $\begin{array}{l}0.007^{\star *} \\
(0.003)\end{array}$ & $\begin{array}{l}0.007^{\star *} \\
(0.003)\end{array}$ & $\begin{array}{l}0.007^{* *} \\
(0.003)\end{array}$ & $\begin{array}{l}0.007^{*} \\
(0.003)\end{array}$ & $\begin{array}{l}0.009^{* *} \\
(0.004)\end{array}$ \\
\hline GMO testing time & $\begin{array}{l}-0.000 \\
(0.145)\end{array}$ & $\begin{array}{l}-0.023 \\
(0.148)\end{array}$ & $\begin{array}{l}-0.099 \\
(0.157)\end{array}$ & $\begin{array}{l}-0.145 \\
(0.163)\end{array}$ & $\begin{array}{l}-0.119 \\
(0.159)\end{array}$ & $\begin{array}{l}-0.059 \\
(0.157)\end{array}$ & $\begin{array}{l}-0.050 \\
(0.159)\end{array}$ & $\begin{array}{l}-0.078 \\
(0.168)\end{array}$ \\
\hline Total scientific journal publications $†$ & $\begin{array}{c}0.011 \\
(0.168)\end{array}$ & $\begin{array}{c}0.003 \\
(0.171)\end{array}$ & $\begin{array}{l}-0.056 \\
(0.183)\end{array}$ & $\begin{array}{c}-0.062 \\
(0.188)\end{array}$ & $\begin{array}{l}-0.050 \\
(0.186)\end{array}$ & $\begin{array}{l}-0.085 \\
(0.180)\end{array}$ & $\begin{array}{l}-0.083 \\
(0.182)\end{array}$ & $\begin{array}{l}-0.119 \\
(0.187)\end{array}$ \\
\hline Tenor of journal publications & $\begin{array}{l}-1.169^{*} \\
(0.609)\end{array}$ & $\begin{array}{l}-1.152^{*} \\
(0.629)\end{array}$ & $\begin{array}{c}-1.703^{* *} \\
(0.694)\end{array}$ & $\begin{array}{c}-1.638^{* *} \\
(0.704)\end{array}$ & $\begin{array}{c}-1.649^{* *} \\
(0.695)\end{array}$ & $\begin{array}{c}-2.007^{* * *} \\
(0.757)\end{array}$ & $\begin{array}{c}-1.808^{* \star *} \\
(0.698)\end{array}$ & $\begin{array}{c}-1.986^{* * *} \\
(0.762)\end{array}$ \\
\hline $\begin{array}{l}\text { Journal publications sponsored by } \\
\text { firm }\end{array}$ & & & & & & & & \\
\hline firm & $\begin{array}{l}-0.036 \\
(0.071)\end{array}$ & $\begin{array}{l}-0.084 \\
(0.082)\end{array}$ & $\begin{array}{l}-0.100 \\
(0.089)\end{array}$ & $\begin{array}{l}-0.097 \\
(0.160)\end{array}$ & $\begin{array}{l}-0.083 \\
(0.090)\end{array}$ & $\begin{array}{l}-0.070 \\
(0.085)\end{array}$ & $\begin{array}{l}-0.082 \\
(0.086)\end{array}$ & $\begin{array}{l}-0.018 \\
(0.089)\end{array}$ \\
\hline Phenotype variety & $\begin{array}{l}-0.604 \\
(0.531)\end{array}$ & $\begin{array}{l}-0.424 \\
(0.531)\end{array}$ & $\begin{array}{l}-0.379 \\
(0.619)\end{array}$ & $\begin{array}{l}-0.695 \\
(0.689)\end{array}$ & $\begin{array}{l}-0.616 \\
(0.683)\end{array}$ & $\begin{array}{l}-0.528 \\
(0.568)\end{array}$ & $\begin{array}{l}-0.429 \\
(0.546)\end{array}$ & $\begin{array}{l}-0.647 \\
(0.612)\end{array}$ \\
\hline Plant-incorporated protectants & $\begin{array}{c}0.366 \\
(0.789)\end{array}$ & $\begin{array}{c}0.227 \\
(0.811)\end{array}$ & $\begin{array}{c}0.200 \\
(0.884)\end{array}$ & $\begin{array}{c}0.025 \\
(0.908)\end{array}$ & $\begin{array}{c}0.198 \\
(0.895)\end{array}$ & $\begin{array}{c}0.264 \\
(0.889)\end{array}$ & $\begin{array}{c}0.355 \\
(0.903)\end{array}$ & $\begin{array}{c}0.176 \\
(0.914)\end{array}$ \\
\hline GMO submission density & $\begin{array}{c}0.263 \\
(0.293)\end{array}$ & $\begin{array}{c}0.288 \\
(0.294)\end{array}$ & $\begin{array}{c}0.429 \\
(0.311)\end{array}$ & $\begin{array}{c}0.377 \\
(0.317)\end{array}$ & $\begin{array}{c}0.431 \\
(0.313)\end{array}$ & $\begin{array}{c}0.420 \\
(0.310)\end{array}$ & $\begin{array}{c}0.479 \\
(0.313)\end{array}$ & $\begin{array}{c}0.391 \\
(0.317)\end{array}$ \\
\hline Public-interest factors & & & & & & & & \\
\hline Congressional conservatism & $\begin{array}{l}-14.205 \\
(69.275)\end{array}$ & $\begin{array}{l}-22.181 \\
(69.489)\end{array}$ & $\begin{array}{l}-32.785 \\
(73.141)\end{array}$ & $\begin{array}{l}-13.287 \\
(75.386)\end{array}$ & $\begin{array}{l}-30.019 \\
(73.621)\end{array}$ & $\begin{array}{c}-30.175 \\
(72.291)\end{array}$ & $\begin{array}{l}-39.279 \\
(73.268)\end{array}$ & $\begin{array}{l}-11.804 \\
(74.879)\end{array}$ \\
\hline Consumer-group concerns about & & & & & & & & \\
\hline GMOs & $\begin{array}{c}0.447 \\
(0.388)\end{array}$ & $\begin{array}{c}0.368 \\
(0.399)\end{array}$ & $\begin{array}{c}0.393 \\
(0.454)\end{array}$ & $\begin{array}{c}0.443 \\
(0.473)\end{array}$ & $\begin{array}{c}0.412 \\
(0.458)\end{array}$ & $\begin{array}{c}0.565 \\
(0.475)\end{array}$ & $\begin{array}{c}0.463 \\
(0.442)\end{array}$ & $\begin{array}{c}0.639 \\
(0.478)\end{array}$ \\
\hline Firm press releases $\dagger$ & $\begin{array}{l}-0.030 \\
(0.178)\end{array}$ & $\begin{array}{l}-0.015 \\
(0.181)\end{array}$ & $\begin{array}{c}0.058 \\
(0.208)\end{array}$ & $\begin{array}{c}0.138 \\
(0.216)\end{array}$ & $\begin{array}{c}0.068 \\
(0.208)\end{array}$ & $\begin{array}{c}0.041 \\
(0.215)\end{array}$ & $\begin{array}{l}-0.091 \\
(0.218)\end{array}$ & $\begin{array}{c}0.024 \\
(0.230)\end{array}$ \\
\hline Wald Chi Squared & $58.79^{\star *}$ & $61.13^{* *}$ & $71.94^{\star * *}$ & $73.52^{\star \star *}$ & $73.62^{* * *}$ & 74.50 *** & $75.19^{* * *}$ & $82.14^{* * *}$ \\
\hline
\end{tabular}


Figure 1. Theoretical Model of the Regulatory Approval Process

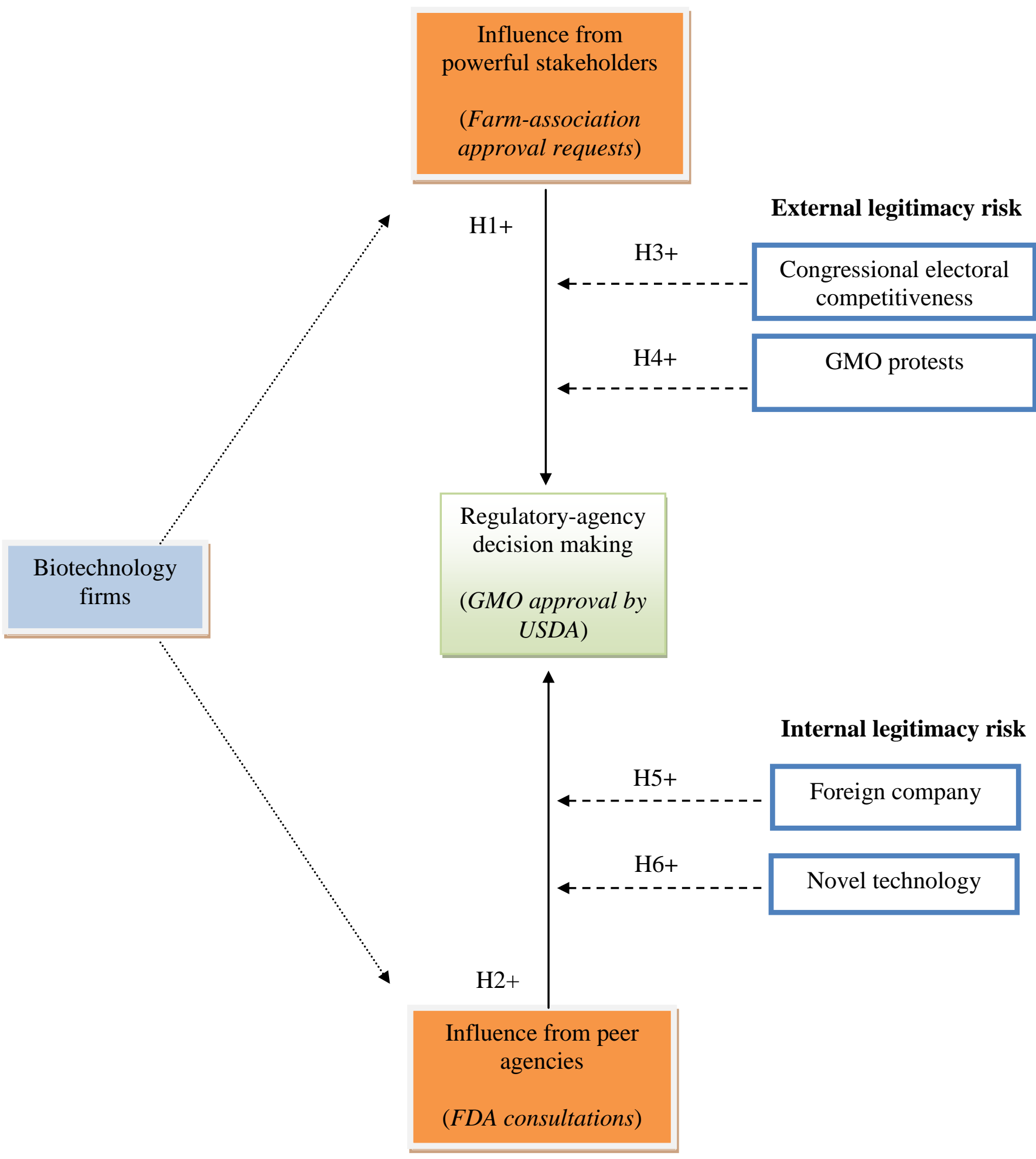


Figure 2. Interaction graphs of farm association approval requests with congressional competitiveness and GMO protests
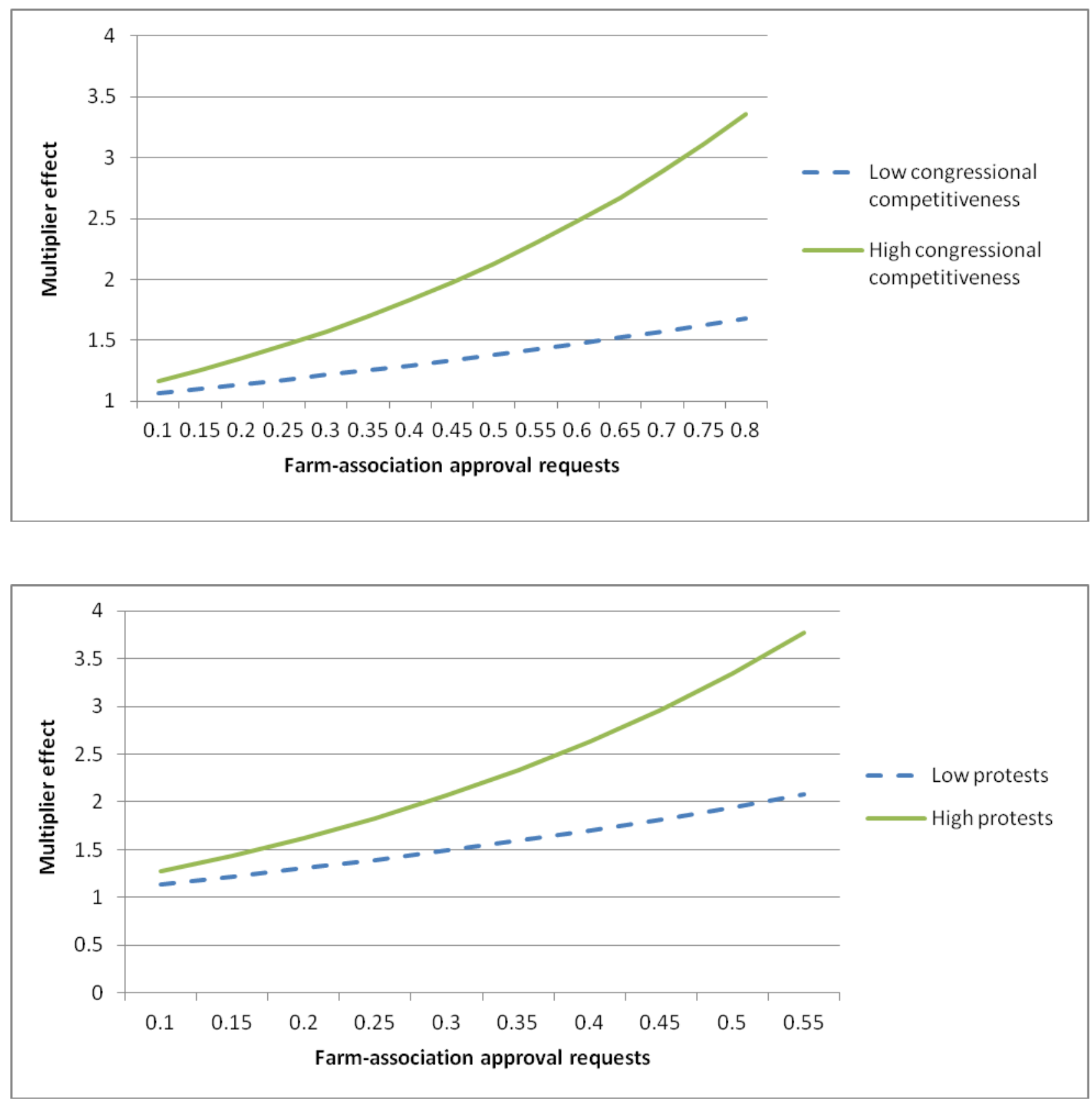
Figure 3. Interaction graphs of FDA consultation with international firm and novel technology
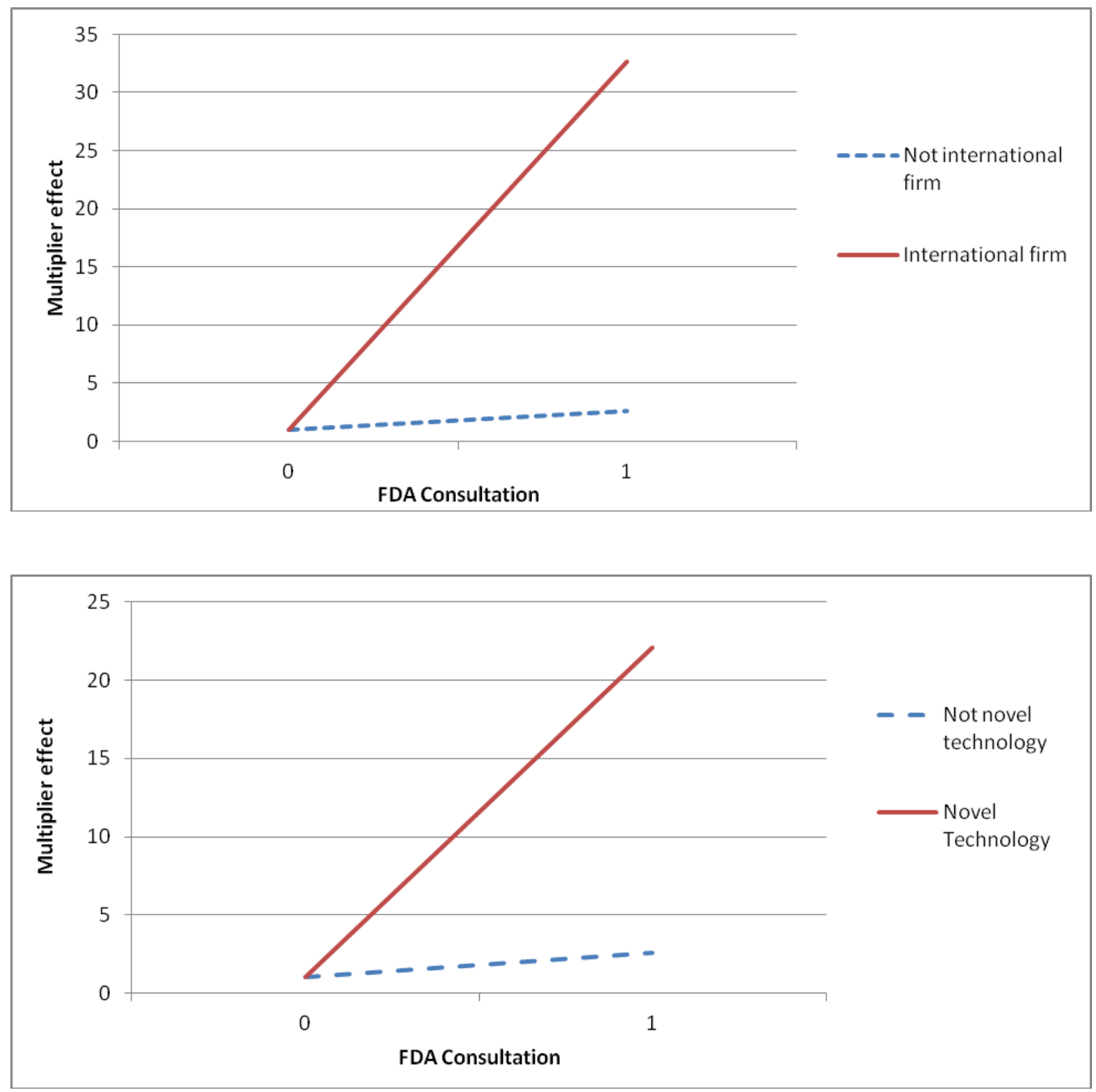
Shon R. Hiatt (shiatt@ hbs.edu) is an assistant professor of business administration at Harvard Business School. He received his Ph.D. from Cornell University. His current research focuses on issues related to entrepreneurship, private and public politics, business-government relations, and nonmarket strategy.

Sangchan Park (scpark@ewha.ac.kr) is an assistant professor of business administration at Ewha Womans University. He received his Ph.D. from Cornell University. His research interests include organization theory, business-government relations and institutional change, with a focus on the legitimation of non-legitimate ideas and work practices. 